\title{
Methanol-assisted autocatalysis in catalytic methanol synthesis
}

Thrane, Joachim; Kuld, Sebastian; Nielsen, Niels D.; Jensen, Anker D.; Sehested, Jens; Christensen, Jakob M.

Published in:

Angewandte Chemie International Edition

Link to article, DOI:

10.1002/anie.202006921

Publication date:

2020

Document Version

Peer reviewed version

Link back to DTU Orbit

Citation (APA):

Thrane, J., Kuld, S., Nielsen, N. D., Jensen, A. D., Sehested, J., \& Christensen, J. M. (2020). Methanol-assisted autocatalysis in catalytic methanol synthesis. Angewandte Chemie International Edition, 59(41), 18189-18193. https://doi.org/10.1002/anie.202006921

\section{General rights}

Copyright and moral rights for the publications made accessible in the public portal are retained by the authors and/or other copyright owners and it is a condition of accessing publications that users recognise and abide by the legal requirements associated with these rights.

- Users may download and print one copy of any publication from the public portal for the purpose of private study or research.

- You may not further distribute the material or use it for any profit-making activity or commercial gain

- You may freely distribute the URL identifying the publication in the public portal

If you believe that this document breaches copyright please contact us providing details, and we will remove access to the work immediately and investigate your claim 


\title{
Methanol assisted autocatalysis in catalytic methanol synthesis
}

Joachim Thrane $^{[a]}$, Sebastian Kuld ${ }^{[b]}$, Niels D. Nielsen ${ }^{[a]}$, Anker D. Jensen ${ }^{[a]}$, Jens Sehested ${ }^{[b]}$ and Jakob M. Christensen*[a]

${ }^{[a]}$ Department of Chemical and Biochemical Engineering

Technical University of Denmark

Søltofts Plads B229, 2800 Kgs. Lyngby (Denmark)

${ }^{[b]}$ Haldor Topsøe A/S

Nymøllevej 55, 2800 Kgs. Lyngby (Denmark)

\begin{abstract}
Catalytic methanol synthesis is one of the major processes in the chemical industry and may grow in importance, as methanol produced from $\mathrm{CO}_{2}$ and sustainably derived $\mathrm{H}_{2}$ is envisioned to play an important role as energy carrier in a future low $\mathrm{CO}_{2}$ emission society. However, despite the widespread use, the reaction mechanism and the nature of the active sites are not fully understood. Here we report that methanol synthesis at commercially applied conditions using the industrial $\mathrm{Cu} / \mathrm{ZnO} / \mathrm{Al}_{2} \mathrm{O}_{3}$ catalyst is dominated by a methanol-assisted, autocatalytic reaction mechanism. We propose that the presence of methanol opens for hydrogenation of surface formate via methyl formate. Autocatalytic acceleration of the reaction is also observed for $\mathrm{Cu}$ supported on $\mathrm{SiO}_{2}$ although with low absolute activity, but not for $\mathrm{Cu} / \mathrm{Al}_{2} \mathrm{O}_{3}$ catalysts. The results illustrate an important example of autocatalysis in heterogeneous catalysis and pave the way for further understanding, improvements and process optimization of industrial methanol synthesis.
\end{abstract}

\section{Introduction}

Heterogeneous catalysis is vital to modern chemical industry. Understanding the nature of the active sites, reaction mechanisms and the origin of metal-support/promoter interactions is therefore not only fundamentally important, but also significant due to the substantial economic impact of improvements to large-scale industrial processes relying on catalysis. Methanol is a major bulk chemical with a production exceeding 70 million tons/year and is produced from syngas $\left(\mathrm{CO} / \mathrm{CO}_{2} / \mathrm{H}_{2}\right)$ over a $\mathrm{Cu} / \mathrm{ZnO} / \mathrm{Al}_{2} \mathrm{O}_{3}$ catalyst ${ }^{[1]}$. Methanol synthesis can proceed over $\mathrm{Cu}$ surfaces, but the reaction rate is strongly enhanced by the presence of zinc in the catalyst ${ }^{[2-5]}$. However, the exact nature of the active sites and the beneficial support effect from $\mathrm{ZnO}$ in the industrial catalyst are still debated issues. By contrast, there seems to be a more widespread agreement concerning the general reaction mechanism for methanol synthesis over $\mathrm{Cu}$ catalysts. Most theoretical and experimental studies advocate that methanol is made directly from carbon dioxide $\left(\mathrm{CO}_{2}\right)$ and hydrogen $\left(\mathrm{H}_{2}\right)$ via formation of surface formate and its subsequent hydrogenation to methanol, and this reaction mechanism explains most reported data in the literature. Yet, such a mechanism is not able to explain some of the most remarkable observations, where methanol synthesis rates under certain conditions are accelerated with increasing conversio $\mathrm{n}^{[6,7]}$. This acceleration is highly unexpected, as the methanol synthesis has a relatively unfavourable equilibrium and experiences a strong kinetic inhibition from the accompanying water product ${ }^{[7-10]}$. Here, we demonstrate that the origin of this obvious inconsistency between theoretical understanding and experimental data is a previously unknown, methanol-assisted, autocatalytic reaction pathway. Our data confirm that this reaction pathway is responsible for most of the turnovers to methanol under industrial conditions, and we conclude that the autocatalytic mechanism most likely is via a methyl formate intermediate.

\section{Results and Discussion}


A series of $\mathrm{Cu}$ catalysts supported on $\mathrm{ZnO} / \mathrm{Al}_{2} \mathrm{O}_{3}, \mathrm{ZnO}, \mathrm{Al}_{2} \mathrm{O}_{3}$ and $\mathrm{SiO}_{2}$ were prepared, and the active $\mathrm{Cu}$ areas of the catalysts were determined through the oxygen uptake (using O:Cu $\mathrm{Cu}_{\text {surf. }} 1: 2$ and $1.47 \cdot 10^{19} \mathrm{Cu}$ atoms $\left./ \mathrm{m}^{2}\right)^{[11]}$ from $1 \mathrm{~mol} \% \mathrm{~N}_{2} \mathrm{O} / \mathrm{He}$ at $333 \mathrm{~K}$ after reduction in $5 \mathrm{vol} \% \mathrm{H}_{2} / \mathrm{N}_{2}$ at atmospheric pressure and $523 \mathrm{~K} . \mathrm{Cu} / \mathrm{Al}_{2} \mathrm{O}_{3}$ required that the $5 \% \mathrm{H}_{2} / \mathrm{N}_{2}$ treatment was followed by a $100 \% \mathrm{H}_{2}$ treatment at $523 \mathrm{~K}$ to obtain complete $\mathrm{Cu}$ reduction. The catalytic activity of prereduced catalysts was measured in a flow reactor at $523 \mathrm{~K}$ and 50 bar in syngas $\left(\mathrm{CO} / \mathrm{CO}_{2} / \mathrm{H}_{2}=\right.$ 29.6/2.8/67.6 mol\%), and for each catalyst, the space velocity (SV) was varied by 1-3 orders of magnitude to vary the level of conversion. Turnover frequencies (TOF: methanol formation rate per $\mathrm{Cu}$ surface atom) at the different conversion levels were determined from the $\mathrm{Cu}$ surface areas and the methanol production rates, and Fig. 1 shows the TOF as a function of the methanol concentration at the exit of the reactor.

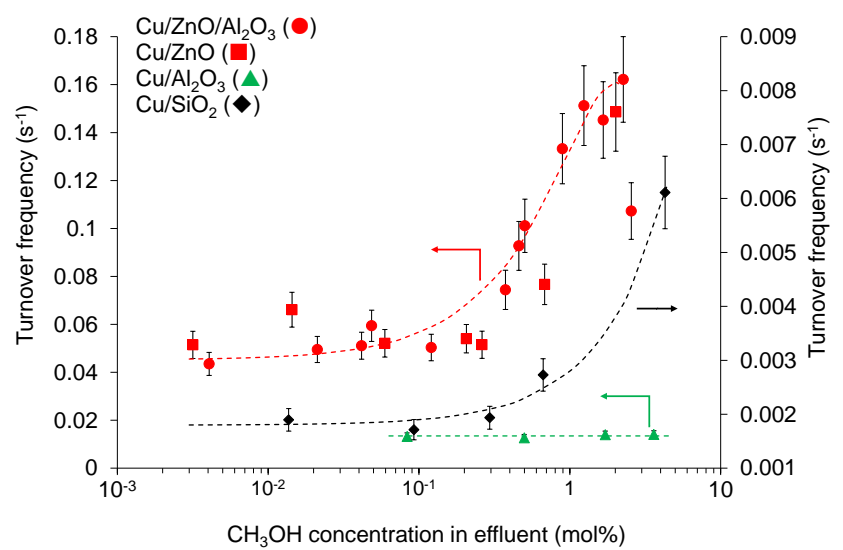

Fig. 1. The dependence of the TOF upon the $\mathrm{CH}_{3} \mathrm{OH}$ concentration in the reactor effluent when varying the space velocity. Note the different scaling of the $\mathrm{Cu} / \mathrm{SiO}_{2}$ data. Dashed lines given as guides to the eye. Experimental conditions: 50 bar, $523 \mathrm{~K}, \mathrm{H}_{2} / \mathrm{CO} / \mathrm{CO}_{2}=67.6 / 29.6 / 2.8 \mathrm{~mol} \%, 3 \cdot 10^{3}-4.3 \cdot 10^{7} \mathrm{NL} / \mathrm{kg} / \mathrm{h}$. See Fig. S1 for a definition of the TOF and a comparison in terms of space velocity. The equilibrium concentration of $\mathrm{CH}_{3} \mathrm{OH}$ at these conditions is $23 \mathrm{~mol} \%$ based on data from Graaf and Winkelman ${ }^{[12]}$.

This figure depicts, how the $\mathrm{Cu}$ catalysts respond to the changing product concentrations, when the SV is varied. Under differential conditions (below approximately $0.1 \mathrm{~mol} \%$ methanol produced), the TOF reaches a stable plateau for each catalyst type. Here methanol formation through a mechanism directly from the reactants must dominate. At these conditions there is a notable support effect on the TOF, and the activity order of the supports $\left(\mathrm{ZnO} / \mathrm{Al}_{2} \mathrm{O}_{3} \cong \mathrm{ZnO}>\right.$ $\mathrm{Al}_{2} \mathrm{O}_{3}>\mathrm{SiO}_{2}$ ) is in good agreement with the observations in several previous studies ${ }^{[2-4]}$. Within the uncertainty the same TOF is seen for $\mathrm{Cu} / \mathrm{ZnO} / \mathrm{Al}_{2} \mathrm{O}_{3}$ and $\mathrm{Cu} / \mathrm{ZnO}$ at identical conversion levels in Fig. 1, and these two systems are therefore treated collectively in the remaining text. The TOFvalues are determined from the $\mathrm{Cu}$ surface areas obtained from $\mathrm{N}_{2} \mathrm{O}$ titrations, and there are uncertainties in methods for determination of metal area, as illustrated by the systematic and carrier-dependent differences between areas from $\mathrm{N}_{2} \mathrm{O}$ and $\mathrm{H}_{2}$ titrations ${ }^{[11]}$. However, with the applied pre-reduction, the magnitude of these differences ${ }^{[11]}$ is expected to be considerably smaller than the differences between the TOF values of the different catalyst systems, and the uncertainties on the area should therefore not affect the conclusions. Consequently, this issue is not discussed further in the following.

Remarkable changes in TOF are observed in Fig. 1 when the product concentrations are increased by lowering of the SV to achieve finite conversions. Lowering the SV causes the TOF- 
values for the $\mathrm{ZnO}\left(/ \mathrm{Al}_{2} \mathrm{O}_{3}\right)$ and $\mathrm{SiO}_{2}$ containing catalysts to increase more than three-fold. Such an increase with rising product concentration is indicative of a significant autocatalytic effect, whereby the product assists the formation of additional product. The magnitude of the acceleration means that the autocatalytic pathway is at least several times faster than the direct pathway, and as a result the substantial majority of turnovers in the industrial process must arise from the autocatalytic pathway. This autocatalytic behaviour is clearly support-dependent. The $\mathrm{Cu} / \mathrm{SiO}_{2}$ catalyst has a low absolute activity but shows an autocatalytic behaviour like that of $\mathrm{Cu} / \mathrm{ZnO}\left(/ \mathrm{Al}_{2} \mathrm{O}_{3}\right)$, while reaction rates for $\mathrm{Cu} / \mathrm{Al}_{2} \mathrm{O}_{3}$ are independent of $\mathrm{SV}$ (see also Supporting Information Fig. S1d). The heat generated in the exothermic reaction increases with conversion/product concentration regardless of the support, but here no significant temperature rise was observed, and the fact that TOF for $\mathrm{Cu} / \mathrm{Al}_{2} \mathrm{O}_{3}$ did not grow with conversion shows that the acceleration is not due to a temperature rise. As $\mathrm{CO}_{2}$ is the primary reactant in methanol synthesis over pure $\mathrm{Cu}$ and $\mathrm{Cu} / \mathrm{ZnO}\left(/ \mathrm{Al}_{2} \mathrm{O}_{3}\right)^{[9,13,14]}$ it is important to evaluate, if changes in $\mathrm{CO}_{2}$ concentration can arise from the variations in conversion. $\mathrm{CO}_{2}$ is consumed via methanol synthesis (R1), but partly restored by the water-gas shift reaction (R2).
$\mathrm{CO}_{2}+3 \mathrm{H}_{2} \rightleftharpoons \mathrm{CH}_{3} \mathrm{OH}+\mathrm{H}_{2} \mathrm{O}$
R1
$\mathrm{CO}+\mathrm{H}_{2} \mathrm{O} \rightleftharpoons \mathrm{H}_{2}+\mathrm{CO}_{2}$
$\mathrm{R} 2$

The activity peak for $\mathrm{Cu} / \mathrm{ZnO}\left(/ \mathrm{Al}_{2} \mathrm{O}_{3}\right)$ in Fig. $1(+372 \%)$ occurs at $2 \mathrm{~mol} \%$ methanol in the effluent. If $\mathrm{R} 2$ is equilibrated at these conditions there will be a $2.5 \%$ net conversion of the $\mathrm{CO}_{2}$. However, the volume contraction due to the loss of molecules in R1 was measured to be $4 \%$ at these conditions, and this leads to a corresponding rise in the $\mathrm{CO}_{2}$ concentration. The consumption of $\mathrm{CO}_{2}$ and the concentration rise due to volume contraction thus nearly balance out, and the concentration of $\mathrm{CO}_{2}$ is therefore essentially unaffected by the reaction (see Fig. S2). Consequently, reaction-induced changes in $\mathrm{CO}_{2}$ concentration cannot affect the experimental results. As diffusion limitations were ruled out by experiments and calculations (see Supporting Information), it can be ruled out that a local concentration rise within the catalyst pores should affect this conclusion.

The increase in reaction rate in Fig. 1 must therefore arise from the emergence of a faster pathway at higher conversions, and at least two parallel reaction pathways in methanol synthesis are needed to explain the results: a direct conversion of the reactants dominating at differential conditions and a faster autocatalytic route involving a reaction product dominant at higher conversions. At the lower SV, where the autocatalytic pathway prevails, the TOF for $\mathrm{Cu} / \mathrm{ZnO}$ was observed to remain constant across an 8 -fold variation in $\mathrm{Cu}$ surface area, which corresponds to a linear correlation between absolute activity and $\mathrm{Cu}$ surface area (Fig. S3). This would imply that the rate limiting step in the autocatalytic pathway occurs on the metal surface, but there is clearly also an either direct or indirect involvement of the support that is of great importance for the absolute activity.

In the industrial process the syngas feed already contains some methanol due to recirculation of unconverted reactants, and the methanol concentration rises to significant percentages through the reactor ${ }^{[15]}$. Under such conditions, the faster autocatalytic pathway will be responsible for the vast majority of the turnovers and thus dominate the industrial process. 
This conclusion raises the question of, which reaction product that causes such an effect. As the highly selective methanol synthesis produces only two major products, namely $\mathrm{CH}_{3} \mathrm{OH}$ and $\mathrm{H}_{2} \mathrm{O}$, these two products represent the most likely candidates. Additional experiments were therefore conducted with the $\mathrm{Cu} / \mathrm{ZnO} / \mathrm{Al}_{2} \mathrm{O}_{3}$ catalyst $\left(\mathrm{Cu}: \mathrm{Zn}: \mathrm{Al}=6: 3: 1,20 \mathrm{~m}_{\mathrm{Cu}}^{2} / \mathrm{g}_{\text {cat. }}\right)$ to identify the source and possible mechanism of the autocatalytic effect. The methanol synthesis activity was measured for the $\mathrm{Cu} / \mathrm{ZnO} / \mathrm{Al}_{2} \mathrm{O}_{3}$ catalyst at differential conditions $\left(\mathrm{SV}=1.6 \cdot 10^{6} \mathrm{NL} / \mathrm{kg} / \mathrm{h}\right)$ far from equilibrium (< $1000 \mathrm{ppm} \mathrm{CH}_{3} \mathrm{OH}$ produced) with low levels of water added to the syngas feed, and the results are shown in Fig. 2.

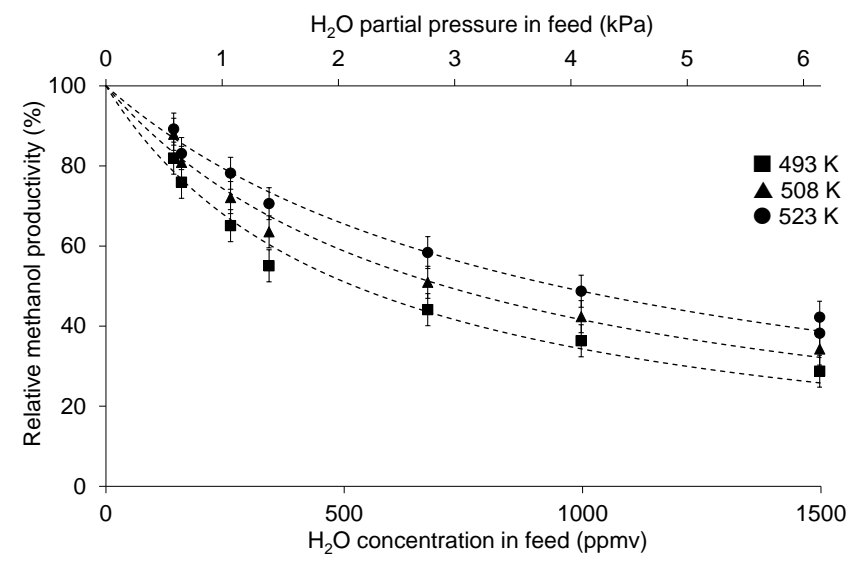

Fig. 2. The relative methanol production as a function of the water content added to the syngas feed. Experimental conditions: Catalyst: $\mathrm{Cu} / \mathrm{ZnO} / \mathrm{Al}_{2} \mathrm{O}_{3}, \mathrm{P}=41 \mathrm{bar}, \mathrm{H}_{2} / \mathrm{CO} / \mathrm{CO}_{2}=67.6 / 29.6 / 2.8 \mathrm{~mol} \%$, $1.6 \cdot 10^{6} \mathrm{NL} / \mathrm{kg} / \mathrm{h}$. Dashed lines given as guides to the eye. See Supporting Information for a definition of the error bars.

The data in Fig. 2 illustrate that even minute amounts of water lower the activity substantially, which strongly indicates that water is not the source of the autocatalytic effect. Competitive adsorption of water or its dissociation products is a likely explanation for this kinetic inhibition, as water adsorption isotherm measurements ${ }^{[16,17]}$ on $\mathrm{Cu} / \mathrm{ZnO} / \mathrm{Al}_{2} \mathrm{O}_{3}$ suggest a high coverage on the $\mathrm{Cu}$ surface at temperatures and $\mathrm{H}_{2} \mathrm{O}$ partial pressures similar to those where major water inhibition is observed in Fig. 2. The increase in TOF with rising product concentrations in Fig. 1 is even more remarkable when considering the strong inhibition caused by the co-produced water.

The effect of adding the second major product, methanol, to the syngas feed is illustrated in Fig. 3. Two independent methanol co-feeding experiments were performed in two very different setups (described in detail in the Supporting Information), and the results are depicted as Figs. 3a and $3 \mathrm{~b}$, respectively. Remarkably, the net rate of methanol formation increases considerably, when methanol is co-fed with the syngas feed, and on this basis we deduce that methanol is the source of the autocatalytic acceleration in methanol synthesis. 
Liquid phase alcohols were previously found ${ }^{[18-20]}$ to accelerate the $\mathrm{Cu}$-catalysed hydrogenation of $\mathrm{CO}_{2}$ to methanol at low temperatures $(\leq 443 \mathrm{~K})$ well below the industrial operating window. However, the data in Fig. 3 imply that methanol synthesis at commercial conditions is dominated by methanol mediated autocatalysis.
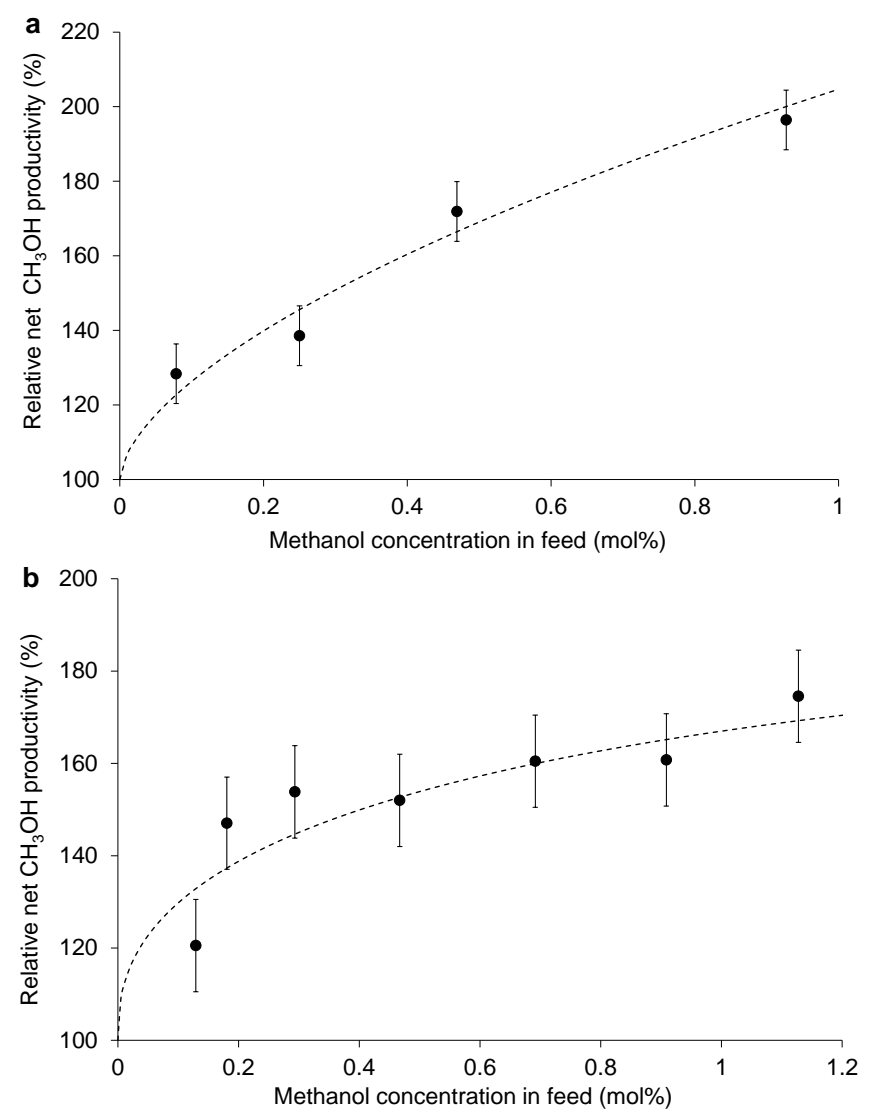

Fig. 3. (a) Relative net productivity of methanol as a function of the methanol concentration in the syngas feed at 50 bar. (b) Relative net productivity of methanol as a function of the methanol concentration in the syngas feed at 41 bar. Other experimental conditions: Catalyst: $\mathrm{Cu} / \mathrm{ZnO} / \mathrm{Al}_{2} \mathrm{O}_{3}, \mathrm{~T}=523 \mathrm{~K}$, syngas before $\mathrm{MeOH}$ addition: $\mathrm{H}_{2} / \mathrm{CO} / \mathrm{CO}_{2}=$ 67.6/29.6/2.8 mol\%, 1.6 $10^{6} \mathrm{NL} / \mathrm{kg} / \mathrm{h}$. Additional data in Figs. S4 and S5. See Supporting Information for a definition of the error bars.

The net increase in reaction rate with increasing conversion seen in a $\mathrm{CO} / \mathrm{CO}_{2} / \mathrm{H}_{2}$ feed (Fig. 1) does not occur in $\mathrm{CO}_{2} / \mathrm{H}_{2}$ gas mixtures as illustrated in Fig. S6. This can be rationalized through the opposite effects of the two reaction products. If $\mathrm{CO}$ is present, most of the produced water will be removed by R2, and the beneficial effect of methanol will dominate over the adverse effect of water. In a CO-free atmosphere, water is produced by both the methanol synthesis and the reverse water-gas shift reaction, and the greater concentration of inhibiting water causes the rate to decline with increasing conversion. However, from a $\mathrm{CO}_{2} / \mathrm{H}_{2}$ feed, only a moderate loss in activity of $6 \%$ was observed for a $\mathrm{Cu} / \mathrm{ZnO} / \mathrm{Al}_{2} \mathrm{O}_{3}$ catalyst at a methanol effluent concentration of $0.4 \mathrm{~mol} \%$ (see Fig. S6). At these conditions, an oxygen balance suggested that $0.68 \mathrm{~mol} \%$ water was co-produced, if only R1 and R2 occur. Considering the inhibition expected from such a water concentration (see Fig. 2), the autocatalytic acceleration seems to partly compensate for the negative effect of water and thus also play a major role in a $\mathrm{CO}_{2} / \mathrm{H}_{2}$ atmosphere. Hence, the net rate of the reaction is determined by the balance between acceleration from the autocatalytic pathway and inhibition 
from produced water, which will depend on the reaction conditions such as the composition of the syngas.

We show here for the first time that methanol formation over the industrially applied $\mathrm{Cu} / \mathrm{ZnO} / \mathrm{Al}_{2} \mathrm{O}_{3}$ catalysts is dominated by an autocatalytic pathway that involves methanol. At high $\mathrm{SV}$ the formed methanol is almost exclusively from $\mathrm{CO}_{2}$ with the industrial $\mathrm{Cu} / \mathrm{ZnO} / \mathrm{Al}_{2} \mathrm{O}_{3}$ catalyst ${ }^{[9,13,14]}$. This is most likely also the case at lower $\mathrm{SV}$, where the rate from a $\mathrm{CO}_{2}$-containing gas ( $>5 \mathrm{~g} \mathrm{geOH} / \mathrm{g}_{\text {cat }} / \mathrm{h}$ in Fig. S1c) is also far higher than in a $\mathrm{CO} / \mathrm{H}_{2}$ feed $\left(0.4 \mathrm{~g} \mathrm{MeOH} / \mathrm{g}_{\mathrm{cat}} / \mathrm{h}\right.$ at comparable conditions ${ }^{[9]}$ ). The autocatalytic pathway at lower SV must therefore be expected to proceed from $\mathrm{CO}_{2}$. At lower $\mathrm{SV} /$ higher conversion with greater water formation more methanol is formed by the $\mathrm{CO} \rightarrow \mathrm{CO}_{2} \rightarrow \mathrm{CH}_{3} \mathrm{OH}$ sequence of $\mathrm{R} 2$ followed by $\mathrm{R} 1$, but the constancy in $\mathrm{CO}_{2}$ concentration across the reactor (Fig. S2) suggests that R2 is fast, and consequently R1 is solely rate limiting in methanol synthesis. Adsorbed formate is present on the metal surface at methanol synthesis conditions ${ }^{[14,21,22]}$, which suggests that the autocatalytic pathway could involve $\mathrm{CO}_{2}$ derived formate. Fig. 4a shows that $\mathrm{CD}_{3} \mathrm{OOCH}$ was formed at low temperature, when $\mathrm{Cu} / \mathrm{ZnO} / \mathrm{Al}_{2} \mathrm{O}_{3}$ with pre-adsorbed $\mathrm{HCOO}$ (from exposure to $\mathrm{HCOOH} / \mathrm{N}_{2}$ at $303 \mathrm{~K}$ ) was subjected to temperature programmed reaction (TPR) in a flow of $\mathrm{CD}_{3} \mathrm{OD}$ in He. This illustrates that methyl formate can be formed from reaction between methanol and surface formate. A role of molecularly adsorbed formic acid cannot be fully excluded here, but previous IR studies ${ }^{[23,24]}$ also demonstrate that the ester is easily formed by reaction of an alcohol with adsorbed formate at typical methanol synthesis temperatures. A probable pathway for the autocatalytic process is therefore via formation of the methyl formate ester from methanol and surface formate (R3) followed by hydrogenation of the ester (R4). However, methyl formate may also be decarbonylated to methanol and $\mathrm{CO}$ $(\mathrm{R} 5)^{[25]}$.

$$
\begin{array}{ll}
\mathrm{CH}_{3} \mathrm{OH}+\mathrm{HCOO} \rightleftharpoons \mathrm{CH}_{3} \mathrm{OOCH}+\mathrm{OH} & \mathrm{R} 3 \\
\mathrm{CH}_{3} \mathrm{OOCH}+2 \mathrm{H}_{2} \rightleftharpoons 2 \mathrm{CH}_{3} \mathrm{OH} & \text { R4 } \\
\mathrm{CH}_{3} \mathrm{OOCH} \rightleftharpoons \mathrm{CH}_{3} \mathrm{OH}+\mathrm{CO} & \text { R5 }
\end{array}
$$

Reaction R3 followed by reaction R4 results in a net gain of methanol, whereas the combination of R3 and R5 yields no net gain. Effective autocatalysis via methyl formate therefore relies on the rates of $\mathrm{R} 3$ and $\mathrm{R} 4$ being faster than direct $\mathrm{CO}_{2}$ hydrogenation and on a high selectivity to hydrogenation (R4) relative to decarbonylation (R5) in the conversion of methyl formate. Fig. $4 \mathrm{~b}$ shows the results, when $\mathrm{Cu} / \mathrm{ZnO} / \mathrm{Al}_{2} \mathrm{O}_{3}$ pre-covered with surface formate (from $\mathrm{HCOOH}$ ) was subjected to a TPR in a flow of either $\mathrm{CH}_{3} \mathrm{OH} / \mathrm{He}$ or $\mathrm{H}_{2}$. Fig. $4 \mathrm{~b}$ illustrates that the onset of methyl formate formation in a $\mathrm{CH}_{3} \mathrm{OH} / \mathrm{He}$ gas occurs at a lower temperature than methanol formation in $\mathrm{H}_{2}$. Re-adsorption phenomena can delay the appearance of a product in a TPH, but the lower onset temperature does indicate that R3 is considerably faster than direct hydrogenation of HCOO, and there are good indications in the literature that this is also the case for both R4 and R5. Fakley and co-workers ${ }^{[26]}$ used the data from Monti et al. ${ }^{[25]}$ to calculate that $\mathrm{R} 4$ should be of ample rate on $\mathrm{Cu}$ to account for an acceleration of the methanol synthesis. 

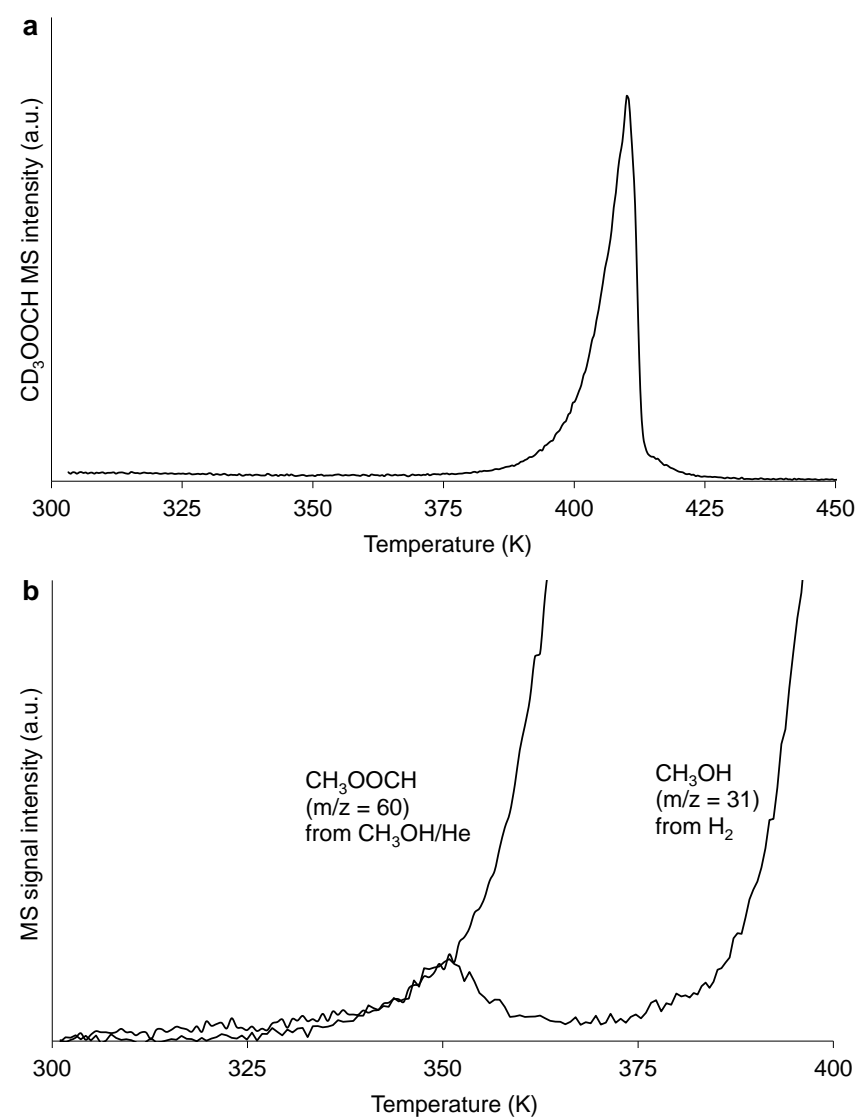

Fig. 4. (a) The formation of methyl formate $\left(\mathrm{CD}_{3} \mathrm{OOCH}, \mathrm{m} / \mathrm{z}=63\right)$ as a function of temperature during TPR when $\mathrm{HCOO}$-covered $\mathrm{Cu} / \mathrm{ZnO} / \mathrm{Al}_{2} \mathrm{O}_{3}$ was heated $(1 \mathrm{~K} / \mathrm{min})$ at $1 \mathrm{~atm}$ in a $19 \mathrm{NmL} / \mathrm{min}$ flow of $4.1 \mathrm{~mol} \% \mathrm{CD}_{3} \mathrm{OD}$ in $\mathrm{He}, 0.5$ g cat. See Fig. S7 for details on peak shape. (b) Comparison of the onset of methyl formate formation during TPR in $5.5 \mathrm{~mol} \% \mathrm{CH}_{3} \mathrm{OH}$ in $\mathrm{He}$ and the onset of methanol formation during TPR in $100 \% \mathrm{H}_{2}$ when formate covered $\mathrm{Cu} / \mathrm{ZnO} / \mathrm{Al}_{2} \mathrm{O}_{3}$ was subjected to TPR at $1 \mathrm{~atm}$. Ramp: $1 \mathrm{~K} / \mathrm{min}$, Flow: $40 \mathrm{NmL} / \mathrm{min}, 0.5 \mathrm{~g}$ cat.

Santiago et al. ${ }^{[27]}$ co-fed methyl formate with the synthesis gas, and their results showed that methyl formate was rapidly converted over $\mathrm{Cu} / \mathrm{ZnO}\left(/ \mathrm{Al}_{2} \mathrm{O}_{3}\right)$ and $\mathrm{Cu} / \mathrm{Al}_{2} \mathrm{O}_{3}$ catalysts at $473 \mathrm{~K}$ and 65 bar. We infer from their data that the additional production of methanol due to methyl formate co-feeding was almost twice as high for $\mathrm{Cu} / \mathrm{ZnO} / \mathrm{Al}_{2} \mathrm{O}_{3}$ compared to $\mathrm{Cu} / \mathrm{Al}_{2} \mathrm{O}_{3}$, which suggests a preference for $\mathrm{R} 4$ on $\mathrm{Cu} / \mathrm{ZnO} / \mathrm{Al}_{2} \mathrm{O}_{3}$ and a preference for $\mathrm{R} 5$ on $\mathrm{Cu} / \mathrm{Al}_{2} \mathrm{O}_{3}$. A preference for $\mathrm{R} 5$ on $\mathrm{Cu} / \mathrm{Al}_{2} \mathrm{O}_{3}$ is further supported by the results of Lam et al. ${ }^{[23]}$, who observed decarbonylation of methyl formate over $\mathrm{Cu} / \mathrm{Al}_{2} \mathrm{O}_{3}$ and found that $\mathrm{R} 5$ is catalysed by the $\mathrm{Al}_{2} \mathrm{O}_{3}$ support. By contrast, $\mathrm{Cu} / \mathrm{ZnO}$-systems ${ }^{[28]}$ and $\mathrm{Cu} / \mathrm{SiO}_{2}$-systems ${ }^{[25]}$ preserve a high selectivity to $\mathrm{R} 4$ versus $\mathrm{R} 5$ also at high temperatures, possibly because these supports are less likely to catalyse R5. A pathway via methyl formate would thus explain the observed support dependence in Fig. 1: i.e. a net acceleration with increasing conversion for the $\mathrm{Cu} / \mathrm{ZnO}\left(/ \mathrm{Al}_{2} \mathrm{O}_{3}\right)$ and $\mathrm{Cu} / \mathrm{SiO}_{2}$ systems, where $\mathrm{R} 4$ dominates, whereas $\mathrm{R} 5$ dominates for $\mathrm{Cu} / \mathrm{Al}_{2} \mathrm{O}_{3}$ and interrupts the autocatalytic pathway. As previously discussed, the net rate is governed by the competition between the autocatalytic acceleration and the water inhibition. Consequently, the conversion independent TOF of $\mathrm{Cu} / \mathrm{Al}_{2} \mathrm{O}_{3}$ in Fig. 1 does not rule out that the autocatalytic pathway proceeds to some extent for $\mathrm{Cu} / \mathrm{Al}_{2} \mathrm{O}_{3}$ 
and partly compensates for inhibiting effects of water, but the efficacy of the autocatalytic pathway is clearly lower for $\mathrm{Cu} / \mathrm{Al}_{2} \mathrm{O}_{3}$ than for the $\mathrm{Cu} / \mathrm{ZnO}\left(/ \mathrm{Al}_{2} \mathrm{O}_{3}\right)$ and $\mathrm{Cu} / \mathrm{SiO}_{2}$ systems.

A consequence of the support dependence in the autocatalytic pathway is that conclusions regarding the difference in TOF between $\mathrm{Cu} / \mathrm{ZnO}\left(/ \mathrm{Al}_{2} \mathrm{O}_{3}\right)$ and $\mathrm{Cu} / \mathrm{Al}_{2} \mathrm{O}_{3}$ are highly dependent on the conditions. Fig. 1 shows that the ratio between their TOF-values increases from a factor of three at differential conditions to more than an order of magnitude at higher conversion. Such variations illustrate the complexity that can emerge in catalytic reactions due to the existence of multiple, parallel reaction pathways with varying dependence on conditions and catalyst composition. This new and more complex picture of the reaction routes over $\mathrm{Cu}$ based methanol synthesis catalysts can possibly help to reconcile some apparent disparities between previous conclusions in the literature. Such complexity arising from the existence of multiple reaction pathways should be a general consideration for catalytic processes, since methanol synthesis may not be the only reaction, where multiple, parallel pathways coexist.

\section{Conclusion}

The discovery of a previously unknown autocatalytic mechanism dominating methanol synthesis at commercial reaction conditions with the industrial catalyst satisfactorily explains the so far unexplained observations $^{[6,7]}$ of increasing methanol synthesis rates with increasing conversion. This novel understanding represents a paradigm shift in the mechanistic interpretation of methanol synthesis and shows that important new discoveries can be made even for well-studied and widely applied catalyst systems. Finally, this breakthrough paves the way for further understanding, improvements and process optimization of industrial methanol synthesis.

\section{Acknowledgements}

This work was supported by a research grant (9455) from VILLUM FONDEN. We thank Saint Gobain for providing the $\mathrm{SiO}_{2}$ support.

\section{References}

[1] J. Sehested, J. Catal. 2019, 371, 368-375.

[2] T. Fujitani, M. Saito, Y. Kanai, T. Kakumoto, T. Watanabe, J. Nakamura, T. Uchijima, Catal. Lett. 1994, 25, 271-276.

[3] M. Saito, K. Murata, Catal. Survey Asia 2004, 8, 285-294.

[4] R. Burch, S. E. Golunski, M. S. Spencer, J. Chem. Soc. Faraday Trans. 1990, 86, 2683-2691.

[5] I. Nakamura, T. Fujitani, T. Uchijima, J. Nakamura, J. Vac. Sci. Technol. A 1996, 14, 14641468.

[6] J. S. Lee, S. H. Han, H. G. Kim, K. H. Lee, Y. G. Kim, Korean J. Chem. Eng. 2000, 17, 332336.

[7] M. Sahibzada, I. S. Metcalfe, D. Chadwick, J. Catal. 1998, 174, 111-118.

[8] O. Cherifi, S. Monteverdi, M. M. Bettahar, M. Forissier, V. Perrichon, Bull. Soc. Chim. Fr. 1985, 405-409.

[9] N. D. Nielsen, J. Thrane, A. D. Jensen, J. M. Christensen, Catal. Lett. 2020, 150, 1427-1433.

[10] Y. Yang, C. A. Mims, D. H. Mei, C. H. F. Peden, C. T. Campbell, J. Catal. 2013, 298, 10-17.

[11] R. Chatterjee, S. Kuld, R. van den Berg, A. Chen, W. Shen, J. M. Christensen, A. D. Jensen, J. Sehested, Top. Catal. 2019, 62, 649-659.

[12] G. H. Graaf, J. G. M. Winkelman, Ind. Eng. Chem. Res. 2016, 55, 5854-5864. 
[13] G. C. Chinchen, P. J. Denny, D. G. Parker, M. S. Spencer, D. A. Whan, Appl. Catal. 1987, 30, 333-338.

[14] N. D. Nielsen, A. D. Jensen, J. M. Christensen, Catal. Lett. in press, DOI: https://doi.org/10.1007/s10562-020-03162-7.

[15] W.-H. Cheng, H. H. Kung (Eds.), Methanol production and use, CRC Press 1994.

[16] J. Słoczyński, R. Grabowski, J. Janas, J. Skrzypek, Chem. Eng. Sci. 1991, 46, 2599-2610.

[17] A. Tarasov, F. Seitz, R. Schlögl, E. Frei, ACS Catal. 2019, 9, 5537-5544.

[18] L. Fan, Y. Sakaiya, K. Fujimoto, Appl. Catal. A 1999, 180, L11-L13.

[19] N. Tsubaki, M. Ito, K. Fujimoto, J. Catal. 2001, 197, 224-227.

[20] P. Reubroycharoen, T. Yamagami, T. Vitidsant, Y. Yoneyama, M. Ito, N. Tsubaki, Energy Fuels 2003, 17, 817-821.

[21] S. Lin, A. Oldfield, D. Klenerman, Surf. Sci. 2000, 464, 1-7.

[22] F. Le Peltier, P. Chaumette, J. Saussey, M. M. Bettahar, J. C. Lavalley, J. Mol. Catal. A 1998, 132, 91-100.

[23] E. Lam, J. J. Corral-Perez, K. Larmier, G. Noh, P. Wolf, A. Comas-Vives, A. Urakawa, C. Coperet, Angew. Chem. Int. Ed. 2019, 58, 13989-13996.

[24] R. Yang, Y. Zhang, N. Tsubaki, Catal. Commun. 2007, 8, 1829-1833.

[25] D. M. Monti, M. S. Wainwright, D. L. Trimm, N. W. Cant, Ind. Eng. Chem. Prod. Des. Dev. 1985, 24, 397-401.

[26] M. E. Fakley, J. R. Jennings, M. S. Spencer, J. Catal. 1989, 118, 483-486.

[27] M. Santiago, K. Barbera, C. Ferreira, D. Curulla-Ferré, P. Kolb, J. Pérez-Ramírez, Catal. Commun. 2012, 21, 63-67.

[28] G. Braca, A. M. R. Galletti, N. J. Laniyonu, G. Sbrana, E. Micheli, M. Di Girolamo, M. Marchionna, Ind. Eng. Chem. Res. 1995, 34, 2358-2363. 